\title{
PEMANFAATAN JURNAL REFLEKSI SEBAGAI STRATEGI METAKOGNITIF DALAM MENINGKATKAN KEAKTIFAN DAN HASIL BELAJAR MATEMATIKA
}

\author{
Khoirul Faizin \\ SMPN 2 Winongan \\ Jl. Raya Jeladri Winongan, Pasuruan, Jawa Timur \\ Email: khofaiz69@gmail.com
}

\begin{abstract}
Abstrak:
Penelitian ini dilatarbelakangi oleh rendahnya keaktifan peserta didik dalam pembelajaran yang berdampak pada rendahnya hasil belajar peserta didik. Secara teoritis, pemanfaatkan jurnal refleksi sebagai strategi metakognitif dapat meningkatkan keaktifan dan hasil belajar peserta didik. Penelitian ini bertujuan untuk mendeskripsikan manfaatkan jurnal refleksi sebagai strategi metakognitif dalam meningkatkan keaktifan dan hasil belajar matematika peserta didik pada materi Kesebangunan Bangun Datar. Jenis penelitian ini adalah penelitian tindakan kelas yang terdiri atas 3 siklus. Subjek pada penelitian ini adalah peserta didik kelas IX-A SMPN 2 Winongan. Pada saat proses penelitian, pengamatan dilakukan terhadap pengelolaan pembelajaran dan keaktifan belajar peserta didik. Pada akhir setiap siklus, diberikan tes hasil belajar matematika. Data yang diperoleh kemudian dianalisis dengan statistik deskriptif. Hasil analisis data menunjukkan bahwa pembelajaran dengan memanfaatkan jurnal refleksi sebagai strategi metakognitif dapat meningkatkan keaktifan dan hasil belajar peserta didik kelas IX-A SMPN 2 Winongan pada materi Kesebangunan Bangun Datar. Dengan demikian, disarankan kepada guru khususnya guru matematika untuk memanfaatkan jurnal refleksi sebagai strategi metakognitif dalam meningkatkan keaktifan dan hasil belajar peserta didik.
\end{abstract}

\begin{abstract}
:
The background of this study was the low activeness of students in learning that impacted on the low learning outcomes. Theoretically, metacognitive strategies utilizing reflection journals can improve the activeness and learning outcomes. The purpose of this study was to describe the learning that utilizes reflective journal as a metacognitive strategy in improving the activity and the result of learning mathematic material of congruent flat surface. This research was classroom action research consisting of 3 cycles, and the subject was the student of class IX-A SMPN 2 Winongan. In the process, observation of the management of learning and student learning activities was done. At the end of each cycle, a mathematics achievement test was given. The data obtained were analyzed by
\end{abstract}


descriptive statistics. The result of data analysis showed that learning by using reflective journal as a metacognitive strategy can increase the students' activeness and their learning outcomes of congruent flat surface material. Then, It is suggested to teachers, especially math teachers to utilize reflective journals as a metacognitive strategy and choose it as an alternative in improving students' activeness and their learning outcomes.

\section{Kata kunci:}

Jurnal Refleksi, Metakognitif, Keaktifan Belajar, Hasil Belajar

Berdasarkan pengalaman selama mengajar di SMPN 2 Winongan sejak Januari 2001, penulis menemukan beberapa masalah yang terjadi dalam proses pembelajaran. Pertama, banyaknya peserta didik yang kurang aktif dalam proses belajar mengajar. Hasil observasi penulis dalam 5 tahun terakhir menunjukkan bahwa rata-rata peserta didik yang mengerjakan tugas di sekolah adalah $50 \%$ dan rata-rata peserta didik yang mengerjakan tugas di rumah adalah $60 \%$. Rendahnya keinginan peserta didik untuk bertanya mengenai materi yang sebenarnya belum dimengerti dan jika diberi pertanyaan, hanya sekitar $15 \%$ peserta didik yang berani menjawab atau memberi tanggapan. Pada saat kegiatan penutup pelajaran, rata-rata peserta didik yang berkonstribusi terhadap kesimpulan belajar hanya $10 \%$.

Kedua, beberapa peserta didik yang saat pembelajaran cukup aktif, sering menjawab pertanyaan, sering tampil mempresentasikan hasil pekerjaannya, dan tugas-tugas dikerjakan dengan baik. Namun, saat ulangan harian hasil yang didapatkan tidak sebaik saat pembelajaran. Sebaliknya, peserta didik yang kelihatannya tidak begitu aktif saat pembelajaran hasil ulangan hariannya lebih baik dibandingkan dengan peserta didik yang aktif.

Ketiga, pada saat pembelajaran guru sering bertanya kepada peserta didik sebagai berikut: "Apakah kamu sudah mengerti apa yang dipelajari tadi? Bagian mana yang masih perlu penjelasan lagi?". Untuk pertanyaan pertama, hanya $10 \%$ peserta didik yang menjawab "sudah mengerti" dan lainnya diam. Sedangkan untuk pertanyaan kedua, tidak ada peserta didik yang menjawab sama sekali. Sehingga sering guru menyimpulkan bahwa mereka sudah mengerti. Namun saat ulangan harian, hasilnya banyak yang di bawah KKM. Hal ini menunjukkan bahwa mereka masih belum mengerti atau menguasai materi yang telah dipelajari.

Keempat, akibat dari kurang aktifnya peserta didik dalam pembelajaran, hasil belajar yang diperoleh belum optimal. Analisis hasil ulangan harian menunjukkan rata-rata $50 \%$ peserta didik tidak tuntas sehingga harus mengikuti program perbaikan. Bahkan setelah mengikuti program perbaikan masih ada peserta didik yang belum tuntas.

Masalah-masalah tersebut juga terjadi pada mata pelajaran matematika di kelas IX-A. Berbagai upaya telah dilakukan untuk mengatasi hal itu, misalnya dengan 
memanggil peserta didik yang nilainya di bawah KKM secara individu. Guru menanyakan mengapa mereka memperoleh nilai di bawah KKM, mengapa mereka tidak mau menjawab ketika ditanya materi yang belum dimengerti, dan mengapa mereka tidak mau bertanya jika masih belum mengerti. Kebanyakan mereka mengatakan malu untuk bertanya dan sebagian mengatakan tidak mengerti apa yang harus ditanyakan. Setelah diberi motivasi dan diberi pengertian tentang pentingnya bertanya, hanya 1 atau 2 peserta didik yang menunjukkan perubahan dalam keaktifan belajar, sedangkan yang lainnya tetap pasif.

Melihat kenyataan tersebut, penulis menyimpulkan bahwa peserta didik kurang memiliki keberanian untuk bertanya di depan teman-temanya, mereka takut kalau diejek. Selain itu, mereka belum mampu mengontrol proses belajarnya sehingga mereka tidak tahu apa yang sudah dipahami dan apa yang belum dipahami. Padahal kemampuan ini sangat diperlukan dalam proses pembelajaran. Dalam ilmu pembelajaran, kesadaran atau pengetahuan seseorang terhadap proses dan hasil berpikirnya serta kemampuannya dalam mengontrol dan mengevaluasi proses kognitifnya dinamakan metakognitif. Shadiq (2013) berdasar pendapat Flavell menjelaskan bahwa metakognitif mengacu pada pengetahuan atau kesadaran seseorang tentang proses berpikir dirinya sendiri, seperti: "Saya sudah menguasai materi ini". Peserta didik yang memiliki kemampuan metakognitif yang baik akan dapat memonitor dan mengarahkan proses belajarnya sendiri, juga memiliki kemampuan untuk menguasai informasi dan menerapkan berbagai strategi belajar untuk memecahkan berbagai masalah dengan lebih mudah.

Salah satu cara melatih kemampuan metakognitif peserta didik adalah dengan menggunakan jurnal refleksi peserta didik. Hasil penelitian Anggraeni (2009) menujukkan bahwa jurnal refleksi berpengaruh secara signifikan terhadap kemampuan metakognitif peserta didik. Septiyana (2012) dalam penelitiannya menyimpulkan bahwa jurnal refleksi dan strategi berpikir metakognitif mempunyai hubungan yang kuat antara keduanya, dan penerapan jurnal refleksi sebagai strategi berpikir metakognitif berpengaruh secara signifikan terhadap hasil belajar peserta didik Penelitian lain juga dilakukan oleh Febriyanti (2009) tentang keefektifan pendekatan keterampilan metakognitif pada pembelajaran matematika yang telah terbukti berpengaruh pada pencapaian hasil belajar peserta didik.

Dalam jurnal refleksi, peserta didik menuliskan apa yang mereka rasakan dalam pembelajaran, termasuk apa yang sudah mereka pahami, apa yang belum mereka pahami, usaha apa yang akan mereka lakukan agar dapat memahami semua materi dan bagaimana cara mengatasi hambatan-hambatan dalam pembelajaran. Sebagian orang menyebut jurnal refleksi ini dengan jurnal belajar. Sabilu dalam penelitiannya menyebut jurnal refleksi dengan jurnal belajar. Demikian juga dengan Anggraeni (2009), Febriyanti (2009) dan Septiyana (2012) menyebut jurnal refleksi dengan jurnal belajar yaitu catatan hasil refleksi diri peserta didik selama pembelajaran yang berisi apa yang telah dimengerti oleh peserta didik, apa yang belum dimengerti oleh peserta didik beserta alasan maupun kendala yang tengah dihadapi, serta apa yang 
akan dilakukan selanjutnya oleh peserta didik terutama berkaitan dengan apa yang belum dimengertinya.

Kesebangunan Bangun Datar merupakan materi matematika yang dipelajari peserta didik di kelas IX semester 1. Menurut pengakuan peserta didik, mereka sering kesulitan dalam menentukan sisi-sisi yang bersesuaian, sudut-sudut yang bersesuaian, dan membuktikan kesebangunan dua bangun datar. Materi ini cukup rumit dan menimbulkan banyak masalah sehingga peserta didik perlu berpikir lebih jauh tentang materi yang dipelajari dan memantau kegiatan belajarnya demi mengoptimalkan hasil belajar. Sementara itu, di sisi lain peserta didik sering merasa malu untuk bertanya dan kurang bisa mengontrol proses belajarnya. Oleh karena itu, dengan jurnal refleksi ini diharapkan dapat mengatasi permasalahan tersebut.

Beberapa keuntungan menulis jurnal refleksi antara lain membantu peserta didik mengetahui apa yang telah dipelajari, bagian mana yang perlu ditingkatkan dan apa yang hendak dicapai, meningkatkan minat dan keterlibatan peserta didik dalam pembelajaran, memberikan gambaran mengenai kemajuan yang didapat, dan masalah yang ditemui serta cara yang memungkinkan untuk mengatasinya. Dengan demikian, jurnal refleksi dapat dijadikan sebagai proses refleksi diri dalam pembelajaran sehingga menjadikan peserta didik lebih percaya diri dalam belajar dan bertanggung jawab terhadap pembelajaran.

Alur pembelajaran yang memanfaatkan jurnal refleksi sebagai strategi metakognitif adalah sebagai berikut:

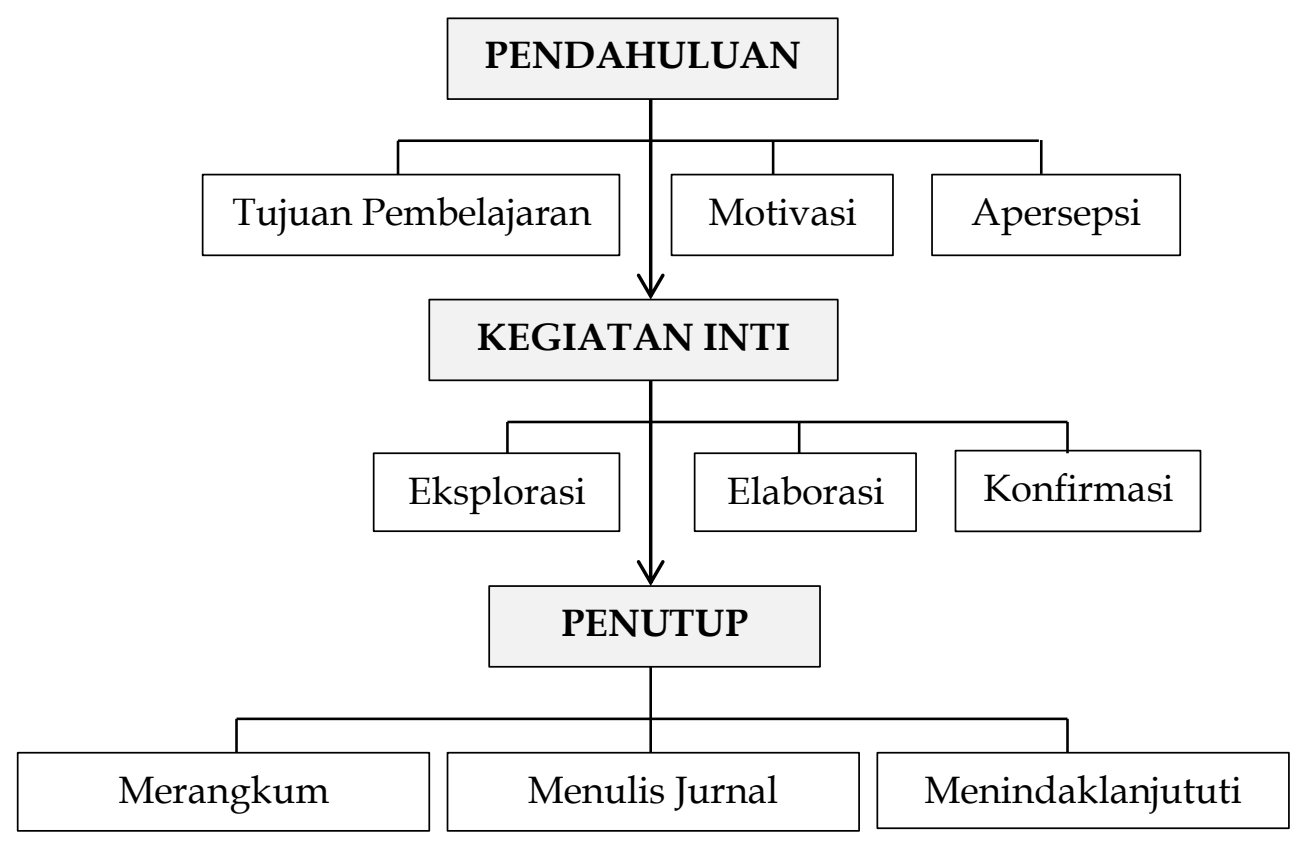

Gambar 1. Alur Pembelajaran dengan Jurnal Refleksi

Pada bagan di atas tampak bahwa menulis jurnal refleksi merupakan bagian dari penutup pembelajaran, dimana peserta didik diminta menulis jurnal refleksi 
pada lembaran yang telah disediakan. Jurnal refleksi adalah semacam buku catatan yang digunakan peserta didik untuk menuangkan perasaannya tentang proses belajar suatu hal (Usaid Prioritas, 2013). Menurut Dwianto (2010) jurnal belajar (jurnal refleksi peserta didik) adalah dokumentasi peserta didik dalam bentuk tulisan mengenai perkembangan materi yang sedang dipelajari. Sementara Suprijono (2010) mengatakan bahwa jurnal dapat dianggap sebagai progress report atas tugas yang dipikul peserta didik. Dengan demikian dapat dikatakan bahwa jurnal refleksi peserta didik adalah catatan yang dibuat peserta didik tentang proses belajarnya dan menggambarkan perkembangan peserta didik dalam mempelajari suatu materi.

Mursyid (Septiyana, 2012) mengatakan bahwa agar jurnal belajar dapat menunjukkan siklus proses pembelajaran maka dalam penulisan jurnal belajar sebaiknya memuat beberapa hal yang meliputi deskripsi (pemaparan apa yang terjadi, apa yang dilihat, atau apa yang dilakukan selama proses pembelajaran), rasa dan pikiran peserta didik (menggambarkan apa yang dirasakan dan dipikirkan sehubungan dengan kegiatan yang dialami selama proses pembelajaran), analisis (peserta didik mencari tahu materi apa yang sudah dan belum dipahami dari proses pembelajaran), kesimpulan (memaparkan kelebihan dan kekurangan dari proses pembelajaran), dan rencana ke depan (menentukan langkah apa yang harus dilakukan untuk memperbaiki kekurangan).

Berkaitan dengan jurnal refleksi, dalam Permendikbud Nomor 22 Tahun 2016 disebutkan bahwa dalam kegiatan penutup pembelajaran, guru bersama peserta didik baik secara individual maupun kelompok melakukan refleksi untuk mengevaluasi seluruh rangkaian aktivitas pembelajaran dan hasil-hasil yang diperoleh untuk selanjutnya secara bersama menemukan manfaat langsung maupun tidak langsung dari hasil pembelajaran yang telah berlangsung. Dengan demikian di akhir pembelajaran, peserta didik diminta melakukan refleksi, baik sendiri-sendiri atau berkelompok. Hasil dari refleksi dapat ditulis atau tidak, namun lebih baik ditulis agar dapat dijadikan bahan pengontrol diri dalam belajar bagi peserta didik, dan bagi guru dapat menjadi bahan pertimbangan untuk merenacanakan pembelajajaran berikutnya. Dalam penelitian ini, guru membimbing peserta didik untuk melakukan refleksi dengan cara menuliskan pada jurnal refleksi tentang apa yang telah dipahami dan belum dipahami, upaya apa yang akan dilakukan berkaitan dengan materi yang belum dipahami, dan bagaimana kesannya terhadap pembelajaran yang telah dilalui.

Berkaitan dengan metakognitif, Teasdale dkk. (2002) mengatakan metakognitif berarti aktivitas kognitifnya sebagai peristiwa mental (kesadaran dari pikiran) sehingga bisa mengontrol apa yang dilakukan. Jonassen (Fadllia, 2012) berdasarkan pendapat Flavel memberikan definisi metakognitif sebagai kesadaran seseorang tentang bagaimana ia belajar, kemampuan untuk menilai kesukaran sesuatu masalah, kemampuan untuk mengamati tingkat pemahaman dirinya, kemampuan menggunakan berbagai informasi untuk mencapai tujuan, dan kemampuan menilai kemajuan belajar sendiri. Sementara Suherman (2001) mengatakan metakognitif 
adalah suatu kata yang berkaitan dengan apa yang diketahui tentang dirinya sebagai individu yang belajar dan bagaimana dia mengontrol serta menyesuaikan perilakunya. Seseorang perlu menyadari kekurangan dan kelebihan yang dimilikinya. Dengan demikian metakognitif adalah kemampuan seseorang untuk menyadari dan mengontrol proses belajar yang dilakukan sehingga dia mengetahui apa yang sudah dapat mereka lakukan dan yang belum mereka kuasai serta dapat merencanakan upaya yang akan dilakukan untuk menguasai seluruh materi pelajaran.

Berdasarkan uraian di atas, tujuan yang ingin dicapai melalui penelitian ini adalah mendeskripsikan memanfaatkan jurnal refleksi sebagai strategi metakognitif dalam meningkatkan keaktifan dan hasil belajar peserta didik kelas IX-A SMPN 2 Winongan pada materi Kesebangunan Bangun Datar.

\section{METODE PENELITIAN}

Penelitian ini dilaksanakan di Kelas IX-A SMPN 2 Winongan Kabupaten Pasuruan pada semester ganjil tahun pelajaran 2016/2017. Pelaksanaan tindakan atau pengambilan data dimulai pada bulan Juli pekan ke-4 sampai September pekan ke-1 tahun 2016 (terpotong 1 pekan untuk kegiatan HUT RI). Jumlah peserta didik kelas IX-A sebanyak 23 orang yang terdiri dari 15 orang laki-laki dan 8 orang perempuan. Dilihat dari kemampuan, latar belakang sosial, ekonomi dan budaya peserta didik kelas ini termasuk heterogen.

Penelitian ini merupakan penelitian tindakan kelas (Classroom Action Research). Pemilihan ini sejalan dengan pendapat Hopkins (Sukidin, dkk., 2002) yaitu penelitian tindakan kelas (PTK) merupakan bentuk kajian refleksi oleh pelaku tindakan dan dilakukan untuk meningkatkan kemampuan guru dalam melaksanakan tugas, memperdalam pemahaman terhadap tindakan-tindakan yang dilakukan, dan memperbaiki kondisi praktek pembelajaran yang telah dilakukan. Jadi dengan PTK, guru dapat mencoba berbagai tindakan yang berupa program pembelajaran tertentu. Dalam pelaksanaan PTK terdapat beberapa model langkah-langkah penelitian. Penelitian ini menggunakan model PTK dari Kemmis dan Taggard dengan tahapantahapan sebagai berikut: (1) perencanaan, (2) tindakan dan Pengamatan, dan (3) refleksi yang dilaksanakan secara berulang atau siklus. Adapun banyak siklus dalam penelitian ini adalah 3 siklus.

Data yang akan dikumpulkan dalam penelitian ini antara lain: (1) data keaktifan peserta didik, (2) hasil pengamatan terhadap langkah-langkah pembelajaran beserta suasana kelas atau respon peserta didik pada saat pembelajaran berlangsung, dan (3) data hasil belajar peserta didik setiap siklus. Sesuai dengan jenis data yang akan dikumpulkan, instrumen yang digunakan dalam penelitian ini adalah: (1) lembar observasi keaktifan peserta didik, (2) lembar observasi kegiatan guru selama pembelajaran beserta respon peserta didik/suasana belajar, dan (3) tes hasil belajar. Pengumpulan data dilakukan dengan teknik observasi dan tes. Teknik observasi digunakan untuk mendapatkan data keaktifan belajar peserta didik dan kegiatan 
guru dalam pembelajaran beserta respon peserta didik. Sedangkan teknik tes digunakan untuk mengetahui hasil belajar peserta didik.

Data keaktifan peserta didik selama pembelajaran yang diperoleh diolah dengan langkah-langkah: menghitung jumlah peserta didik yang melakukan suatu aspek, menghitung persentase peserta didik yang melakukan suatu aspek terhadap keseluruhan peserta didik, dan menentukan keaktifan peserta didik satu siklus untuk setiap aspek dengan cara menghitung rata-rata keaktifan peserta didik setiap pertemuan dalam siklus tersebut. Data hasil belajar peserta didik setiap siklus dianalisis dengan cara menghitung jumlah peserta didik yang tuntas atau yang memperoleh nilai lebih dari atau sama dengan KKM. KKM yang dimaksud adalah KKM yang berlaku untuk KD yang diajarkan sehingga memungkinkan KKM untuk KD yang satu berbeda dengan KKM untuk KD lainnya. Kemudian menghitung persentase peserta didik yang tuntas belajar terhadap keseluruhan peserta didik.

\section{HASIL PENELITIAN DAN PEMBAHASAN}

\section{Hasil Penelitian}

\section{Siklus I}

Pembelajaran pada siklus I terdiri dari 3 pertemuan, yaitu hari Senin tanggal 25 Juli, Rabu tanggal 27 Juli 2016, dan Senin tanggal 1 Agustus 2016. Sedangkan tes hasil belajar akhir siklus I dilaksanakan pada hari Rabu tanggal 3 Agustus 2016. Adapun materi pembelajarannya adalah Kesebangunan dengan KD 1.1: Mengidentifikasi bangun-bangun datar yang sebangun dan kongruen

Hasil pengamatan terhadap keaktifan peserta didik selama pembelajaran pada siklus I yang terdiri dari 3 pertemuan adalah sebagai berikut:

Tabel 1. Data Keaktifan Peserta didik dalam Pembelajaran Pada Siklus I

\begin{tabular}{|c|c|c|c|c|c|c|}
\hline \multirow[t]{2}{*}{ No } & \multirow[t]{2}{*}{ Indikator } & \multicolumn{3}{|c|}{$\begin{array}{c}\text { Banyak Peserta didik } \\
\text { Pertemuan ke }\end{array}$} & \multirow{2}{*}{$\begin{array}{l}\text { Rata- } \\
\text { rata }\end{array}$} & \multirow[t]{2}{*}{ Target } \\
\hline & & 1 & 2 & 3 & & \\
\hline 1 & $\begin{array}{l}\text { Melaksanakan tugas individu } \\
\text { dan terlibat pengerjaan tugas } \\
\text { kelompok }\end{array}$ & $56,52 \%$ & $56,52 \%$ & $65,22 \%$ & $59,42 \%$ & $85 \%$ \\
\hline 2 & $\begin{array}{l}\text { Mengajukan pertanyaan baik } \\
\text { pada guru maupun pada } \\
\text { peserta didik }\end{array}$ & $13,04 \%$ & $17,39 \%$ & $17,39 \%$ & $15,94 \%$ & $20 \%$ \\
\hline 3 & $\begin{array}{l}\text { Berpendapat atau menjawab } \\
\text { pertanyaan guru atau peserta } \\
\text { didik }\end{array}$ & $26,09 \%$ & $21,74 \%$ & $26,09 \%$ & $24,64 \%$ & $30 \%$ \\
\hline 4 & $\begin{array}{l}\text { Mengerjakan tugas rumah } \\
\text { (PR) }\end{array}$ & $73,91 \%$ & $73,91 \%$ & $78,26 \%$ & $75,36 \%$ & $85 \%$ \\
\hline
\end{tabular}


Adapun hasil belajar peserta didik pada siklus I dengan KKM 78 adalah sebagai berikut:

Tabel 2. Hasil Belajar Peserta didik Pada Siklus I

\begin{tabular}{cccccc}
\hline No & $\begin{array}{c}\text { Nilai yang } \\
\text { diperoleh }\end{array}$ & $\begin{array}{c}\text { Jumlah } \\
\text { Peserta didik }\end{array}$ & Prosentase & Ketuntasan & Target \\
\hline 1 & $<$ KKM & 7 & $30,43 \%$ & & \\
2 & $=$ KKM & 6 & $26,09 \%$ & $69,57 \%$ & $80 \%$ \\
3 & $>$ KKM & 10 & $43,48 \%$ & & \\
\hline
\end{tabular}

Berdasarkan data keaktifan dan hasil belajar peserta didik data yang diperoleh, masih belum mencapai target maka penelitian ini perlu dilanjutkan ke siklus II. Pada siklus II akan dilakukan perbaikan-perbaikan tindakan sehingga diharapkan semua aspek pada indikator keberhasilan yang telah ditentukan dapat tercapai.

Hasil analisis terhadap tindakan-tindakan yang kurang mendukung terhadap pencapaian indikator keberhasilan, antara lain:

a. Dengan jurnal refleksi yang hanya berisi 3 pertanyaan, yaitu: materi apa yang sudah dikuasai, materi apa yang belum dikuasai, dan bagaimana kesan terhadap pembelajaran hari ini, ternyata peserta didik belum bisa memanfaatkannya untuk mengontrol aktifitas belajarnya. Oleh karena itu pada siklus II, pada jurnal refleksi ditambah pertanyaan "Apa yang akan anda lakukan untuk memahami materi yang belum anda pahami?".

b. Dalam mengajukan pertanyaan, guru lebih banyak menawarkan kepada peserta didik yang mau menjawab dan tidak menunjuk peserta didik. Sehingga peserta didik yang malu meskipun bisa, tidak perlu menjawab.

c. Pembentukan kelompok yang hanya mempertimbangkan heterogenitas kemampuan akademik menyebabkan beberapa peserta didik merasa tidak nyaman di kelompoknya karena terpisah dari teman akrabnya. Hal ini terjadi terutama pada peserta didik perempuan yang sendirian di kelompoknya.

\section{Siklus II}

Pembelajaran pada siklus II terdiri dari 3 pertemuan, yaitu hari Senin tanggal 8 Agustus 2016, Rabu tanggal 10 Agustus 2016, dan Senin tanggal 22 Agustus 2016. Sedangkan tes hasil belajar akhir siklus II dilaksanakan pada hari Rabu tanggal 24 Agustus 2016. Adapun materi pembelajarannya adalah Kesebangunan dan Kekongruenan Segitiga dengan KD 1.2: Mengidentifikasi sifat-sifat dua segitiga sebangun dan kongruen.

Hasil pengamatan terhadap keaktifan peserta didik selama pembelajaran pada siklus II yang terdiri dari 3 pertemuan terdapat pada tabel 3. Sedangkan hasil belajar peserta didik pada siklus II dengan KKM 77 terdapat pada tabel 4. 
Tabel 3. Data keaktifan Peserta didik dalam Pembelajaran Pada Siklus II

\begin{tabular}{|c|c|c|c|c|c|c|}
\hline \multirow[t]{2}{*}{ No } & \multirow[t]{2}{*}{ Indikator } & \multicolumn{3}{|c|}{$\begin{array}{c}\text { Banyak Peserta didik } \\
\text { Pertemuan ke } \\
\end{array}$} & \multirow{2}{*}{$\begin{array}{l}\text { Rata- } \\
\text { rata }\end{array}$} & \multirow[t]{2}{*}{ Target } \\
\hline & & 1 & 2 & 3 & & \\
\hline 1 & $\begin{array}{l}\text { Melaksanakan tugas } \\
\text { individu dan terlibat } \\
\text { pengerjaan tugas kelompok }\end{array}$ & $82,61 \%$ & $86,96 \%$ & $86,96 \%$ & $85,51 \%$ & $85 \%$ \\
\hline 2 & $\begin{array}{l}\text { Mengajukan pertanyaan } \\
\text { baik pada guru maupun } \\
\text { pada peserta didik }\end{array}$ & $17,39 \%$ & $21,74 \%$ & $17,39 \%$ & $18,84 \%$ & $20 \%$ \\
\hline 3 & $\begin{array}{l}\text { Berpendapat atau } \\
\text { menjawab pertanyaan guru } \\
\text { atau peserta didik }\end{array}$ & $30,43 \%$ & $30,43 \%$ & $34,78 \%$ & $31,88 \%$ & $30 \%$ \\
\hline 4 & Mengerjakan tugas (PR) & $78,26 \%$ & $86,96 \%$ & $91,30 \%$ & $85,51 \%$ & $85 \%$ \\
\hline
\end{tabular}

Tabel 4. Hasil Belajar Peserta didik Pada Siklus II

\begin{tabular}{lccccc}
\hline No & $\begin{array}{c}\text { Nilai yang } \\
\text { diperoleh }\end{array}$ & $\begin{array}{c}\text { Jumlah } \\
\text { Peserta } \\
\text { didik }\end{array}$ & Prosentase & Ketuntasan & Target \\
\hline $\mathbf{1}$ & $<$ KKM & 6 & $26,09 \%$ & & \\
$\mathbf{2}$ & $=$ KKM & 7 & $30,43 \%$ & $73,91 \%$ & $80 \%$ \\
$\mathbf{3}$ & $>$ KKM & 10 & $43,48 \%$ & & \\
\hline
\end{tabular}

Hasil analisis terhadap tindakan-tindakan yang kurang mendukung terhadap pencapaian indikator keberhasilan, antara lain:

a. Dengan menambah pertanyaan pada jurnal refleksi (apa yang akan anda lakukan untuk memahami materi yang belum anda pahami?) jumlah peserta didik yang bertanya tentang materi yang belum dimengerti semakin meningkat meskipun masih kurang. Hal ini bisa dikarenakan mereka mulai bisa memanfaatkan jurnal refleksi untuk mengontrol belajarnya.

b. Seiiring meningkatnya keberanian peserta didik dalam bertanya, waktu yang tersedia tidak mencukupi bagi guru untuk menjelaskan semua pertanyaan secara rinci. Oleh karena itu pada siklus III, selain jurnal refleksi individu juga diberikan jurnal refleksi kelompok.

c. Dalam kerja kelompok, peserta didik laki-laki dan peserta didik perempuan kurang bisa bekerja sama. Mereka masih cenderung malu untuk berdiskusi.

\section{Siklus III}

Pembelajaran siklus III terdiri dari 2 pertemuan, yaitu hari Senin tanggal 29 Agustus 2016 (2 jam pelajaran) dan Rabu tanggal 31 Agustus 2016 (2 jam pelajaran). Sedangkan tes hasil belajar siklus III dilaksanakan pada hari Senin tanggal 5 
September 2016. Adapun materi pembelajarannya adalah kesebangunan dengan KD 1.3, yaitu menggunakan konsep kesebangunan segitiga dalam pemecahan masalah.

Hasil pengamatan terhadap keaktifan belajar peserta didik selama pembelajaran pada siklus III yang terdiri dari 2 pertemuan adalah sebagai berikut:

Tabel 5. Data Keaktifan Peserta didik dalam Pembelajaran Pada Siklus III

\begin{tabular}{clcccc}
\hline \multirow{2}{*}{ No } & \multicolumn{1}{c}{ Indikator } & \multicolumn{2}{c}{ Pertemuan ke- } & \multirow{2}{*}{ Rata-rata } & Target \\
\cline { 3 - 4 } & \multicolumn{1}{c}{$\mathbf{1}$} & $\mathbf{2}$ & \\
\hline \multirow{2}{*}{1} & $\begin{array}{l}\text { Melaksanakan tugas individu } \\
\text { dan terlibat pengerjaan tugas } \\
\text { kelompok }\end{array}$ & $86,96 \%$ & $91,30 \%$ & $89,13 \%$ & $85 \%$ \\
$\quad \begin{array}{l}\text { Mengajukan pertanyaan baik } \\
\text { pada guru maupun pada } \\
\text { peserta didik }\end{array}$ & $17,39 \%$ & $26,09 \%$ & $21,74 \%$ & $20 \%$ \\
$\begin{array}{l}\text { Berpendapat atau menjawab } \\
\text { pertanyaan guru atau peserta } \\
\text { didik }\end{array}$ & $34,78 \%$ & $39,13 \%$ & $36,96 \%$ & $30 \%$ \\
\hline & Mengerjakan tugas (PR) & $86,96 \%$ & $95,65 \%$ & $91,31 \%$ & $85 \%$ \\
\hline
\end{tabular}

Adapun hasil belajar peserta didik pada siklus III dengan KKM 70 adalah sebagai berikut:

Tabel 6. Hasil Belajar Peserta didik Pada Siklus III

\begin{tabular}{lccccc}
\hline No & $\begin{array}{c}\text { Nilai yang } \\
\text { diperoleh }\end{array}$ & $\begin{array}{c}\text { Jumlah } \\
\text { Peserta } \\
\text { didik }\end{array}$ & Prosentase & Ketuntasan & Target \\
\hline 1 & $<$ KKM & 4 & $17,39 \%$ & $82,61 \%$ & $80 \%$ \\
2 & $=$ KKM & 5 & $21,74 \%$ & & \\
3 & $>$ KKM & 14 & $60,87 \%$ & & \\
\hline
\end{tabular}

Hasil pengamatan teman sejawat (kolaborator), menunjukkan adanya tindakantindakan yang mendukung tercapainya indikator keberhasilan, yaitu:

a. Penggunaan jurnal refleksi kelompok, membuat pembelajaran semakin efektif karena peserta didik semakin aktif berdiskusi dan pertanyaan-pertanyaan yang diajukan peserta didik kepada guru semakin selektif dan berkualitas

b. Pembagian kelompok yang memisahkan peserta didik laki-laki dan peserta didik perempuan membuat mereka belajar kelompok dengan perasaan tenang dan nyaman.

Berdasarkan hasil analisis data, dapat disimpulkan bahwa pembelajaran Kesebangunan dengan memanfaatkan jurnal refleksi sebagai strategi metakognitif pada siklus III telah mencapai kondisi ideal yang diharapkan sehingga dapat meningkatkan keaktifan dan hasil belajar peserta didik. 



\section{Pembahasan}

Sebagaiman telah diuraikan di atas bahwa pemanfaatan jurnal rekleksi sebagai strategi metakognitif telah mencapai indikator keberhasilan pada siklus III. Bahkan beberapa aspek pencapaiannya melebihi yang diharapkan. Ringkasan pencapaian indikator keberhasilan dari siklus I sampai siklus III disajikan dalam tabel 7.

Tabel 7. Ringkasan Pencapaian Indikator Keberhasilan Tiap Siklus

\begin{tabular}{|c|c|c|c|c|c|}
\hline \multirow{2}{*}{ No } & \multirow{2}{*}{ Indikator } & \multicolumn{3}{|c|}{ Pencapaian Pada } & \multirow{2}{*}{ Targe } \\
\hline & & Siklus I & Siklus II & Siklus III & \\
\hline $\mathrm{A}$ & Keaktifan Peserta didik & & & & \\
\hline 1 & $\begin{array}{l}\text { Melaksanakan tugas individu } \\
\text { dan terlibat pengerjaan tugas } \\
\text { kelompok }\end{array}$ & $59,42 \%$ & $85,51 \%$ & $89,13 \%$ & $85 \%$ \\
\hline 2 & $\begin{array}{l}\text { Mengajukan pertanyaan baik } \\
\text { pada guru maupun pada } \\
\text { peserta didik }\end{array}$ & $15,94 \%$ & $18,84 \%$ & $21,74 \%$ & $20 \%$ \\
\hline 3 & $\begin{array}{l}\text { Berpendapat atau menjawab } \\
\text { pertanyaan guru atau peserta } \\
\text { didik }\end{array}$ & $24,64 \%$ & $31,88 \%$ & $36,96 \%$ & $30 \%$ \\
\hline 4 & $\begin{array}{l}\text { Mengerjakan tugas rumah } \\
\text { (PR) }\end{array}$ & $75,36 \%$ & $85,51 \%$ & $91,31 \%$ & $85 \%$ \\
\hline 5 & $\begin{array}{l}\text { Jumlah peserta didik yang } \\
\text { tuntas (memperoleh nilai } \geq \\
\text { KKM) }\end{array}$ & $69,57 \%$ & $73,91 \%$ & $82,61 \%$ & $80 \%$ \\
\hline
\end{tabular}

\section{Keaktifan Peserta didik}

Keaktifan belajar peserta didik dalam penelitian ini menggunakan 4 indikator. Indikator pertama adalah melaksanakan tugas, baik individu maupun kelompok. Kondisi awal pencapaian indikator ini hanya 52,17\%. Namun setelah memanfaatkan jurnal refleksi sebagai strategi metakognitif, dari siklus ke siklus pencapaian indikator ini mengalami kenaikan. Bahkan pada siklus kedua sudah melampaui target $85 \%$. 


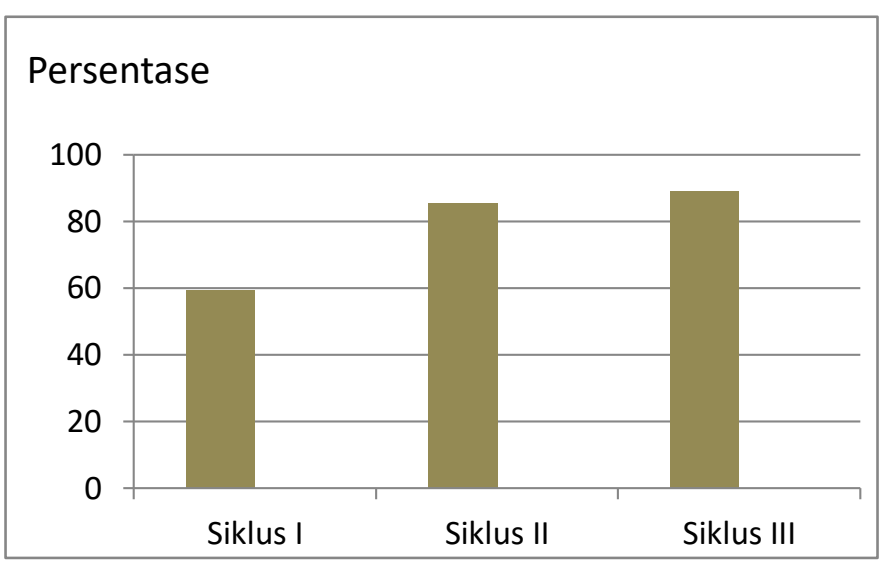

Gambar 2. Diagram Keaktifan Melaksanakan Tugas

Kenaikan yang signikan pada siklus kedua dapat disebabkan adanya tambahan pertanyaan pada jurnal refleksi, yaitu upaya apa yang akan anda lakukan untuk memahami materi yang belum kuasai ?. Dengan pertanyaan ini maka kegiatan belajar peserta didik semakin terkontrol.

Indikator keaktifan yang kedua adalah mengajukan pertanyaan, baik pada guru maupun peserta didik. Indikator ini juga mengalami kenaikan dari siklus ke siklus, dan pada siklus ketiga baru mencapai target $20 \%$. Sementara kondisi awal hanya $8,70 \%$.

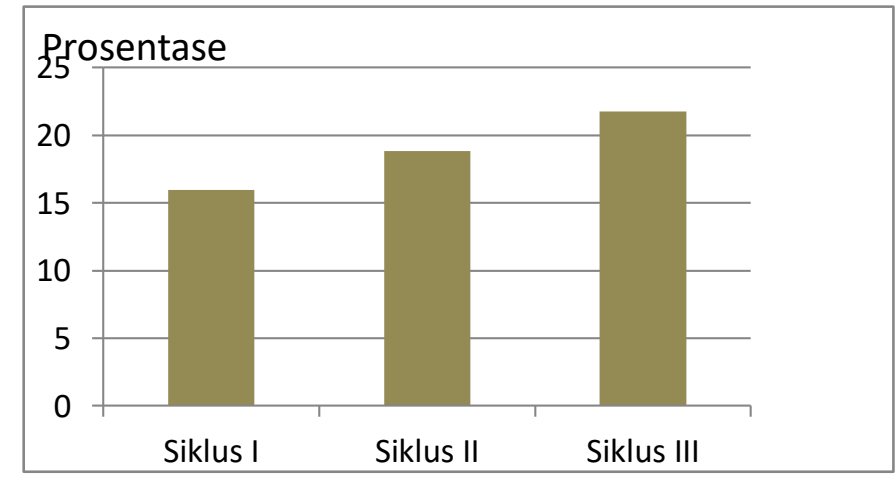

Gambar 3. Diagram Keaktifan Mengajukan Pertanyaan

Kenaikan persentase peserta didik yang bertanya dari siklus ke siklus menandakan bahwa peserta didik mulai bisa memanfaatkan jurnal refleksi untuk mengarahkan belajarnya. Peserta didik berusaha menguasai materi yang belum dipahami dengan bertanya pada guru atau peserta didik lain. Meskipun kebanyakan peserta didik bertanya sambil membaca jurnal refleksi.

Berkaitan dengan indikator keaktifan yang ketiga yaitu mengemukakan pendapat, menjawab pertanyaan guru atau peserta didik lain, kondisi awal menunjukkan hanya 17,39\% peserta didik yang melakukan kegiatan itu. Setelah 
pembelajaran dengan memanfaatkan jurnal refleksi sebagai strategi metakognitif, pencapaian indikator tersebut mengalami peningkatan.

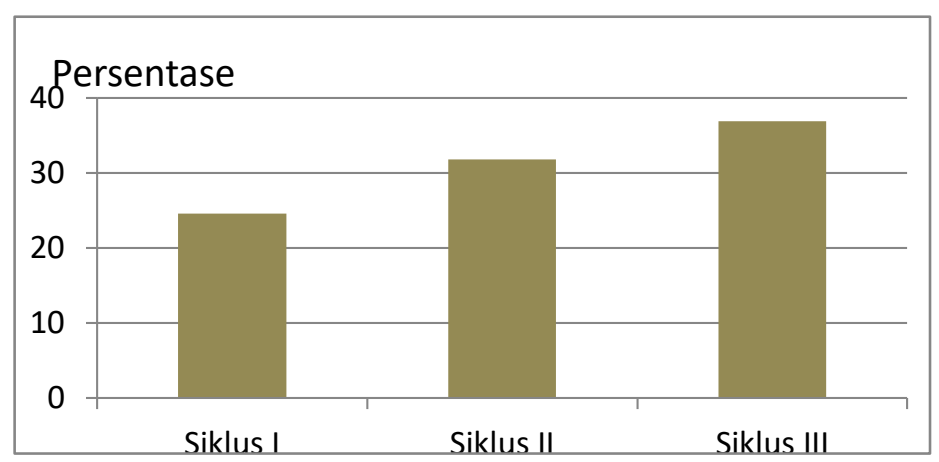

Gambar 4. Diagram Keaktifan Berpendapat atau Menjawab Pertanyaan

Pada diagram tersebut, tampak bahwa persentase keaktifan berpendapat atau menjawab pertanyaan mengalami peningkatan dari siklus ke siklus, bahkan pada siklus kedua sudah melampaui target $30 \%$. Hal ini menunjukkan keberanian dan kemampuan peserta didik juga mengalami peningkatan.

Adapun indikator keaktifan yang keempat yaitu mengerjakan tugas rumah (PR) juga mengalami peningkatan dari siklus ke siklus, bahkan pada siklus kedua telah mencapai target $85 \%$. Sementara kondisi awal menunjukkan hanya $65,22 \%$ peserta didik mengerjakan PR.

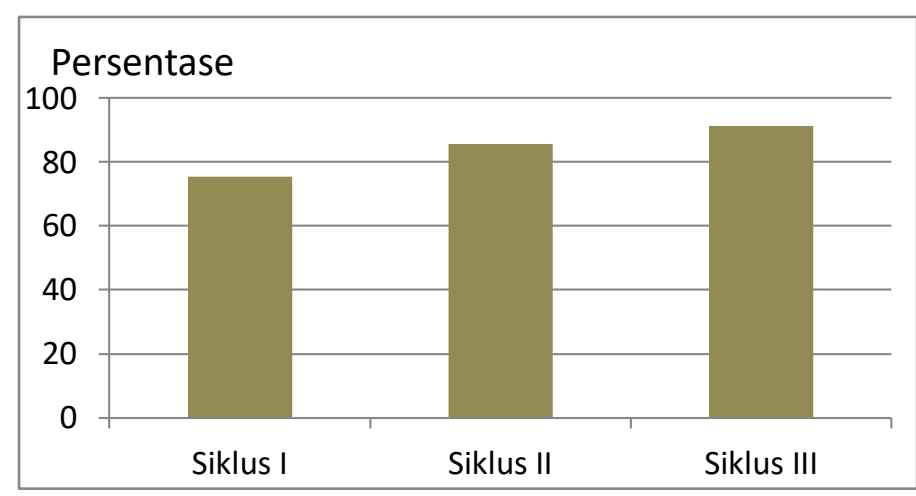

Gambar 5. Diagram Keaktifan Mengerjakan Tugas Rumah

Peningkatan persentase peserta didik yang mengerjakan PR menunjukkan bahwa peserta didik berusaha menguasai materi yang belum dipahami dengan lebih banyak belajar atau berlatih, sebagaimana yang ditulis pada jurnal refleksi.

Data awal menunjukkan bahwa sebelum penelitian atau sebelum memanfaatkan jurnal refleksi sebagai strategi metakognitif dalam pembelajaran, ratarata peserta didik yang mengerjakan tugas (PR) yang diberikan adalah 65\%. Hampir tidak ada peserta didik yang berani bertanya tentang hal-hal yang sebenarnya tidak dimengertinya. Kalau diberi pertanyaan, hanya sekitar $17 \%$ peserta didik yang berani 
menjawab atau menyampaikan pendapat. Pada saat diberi tugas individu maupun kelompok, sekitar 52\% yang terlibat dalam pengerjaan tugas. Hasil belajar mereka juga belum optimal. Peserta didik yang tuntas belajarnya paling banyak $50 \%$.

Namun dengan memanfaatkan jurnal refleksi sebagai strategi metakognitif pada pembelajaran di siklus I, peserta didik yang mau melaksanakan tugas individu dan terlibat dalam pengerjaan tugas kelompok sebanyak 59,42\%, peserta didik yang berani menjawab pertanyaan guru atau peserta didik lain sekitar 36,96\%, peserta didik yang mau bertanya $15,94 \%$. Hasil belajarnya juga meningkat, yaitu peserta didik yang tuntas $69,57 \%$.

Data di atas menunjukkan pada siklus I telah terjadi peningkatan persentase peserta didik yang tuntas berdasarkan hasil belajarnya, dibandingkan sebelum penelitian. Hal ini dapat dipahami mengingat pembelajaran dengan memanfaatkan jurnal refleksi sebagai strategi metakognitif pada siklus I ini telah berhasil meningkatkan keaktifan peserta didik dibandingkan pada pembelajaran sebelumnya. Dengan meningkatnya keaktifan peserta didik dalam belajar maka daya serap peserta didik terhadap materi pembelajaran juga meningkat.

Pada siklus II, keaktifan peserta didik dalam pembelajaran mengalami peningkatan dibandingkan pada siklus I. Dengan menambah pertanyaan pada format jurnal refleksi (tentang upaya yang akan dilakukan untuk mengatasi materi yang belum dipahami), peserta didik semakin dapat memfaatkannya untuk mengontrol belajarnya. Di samping itu, dengan membagikan LKS lebih banyak kepada setiap kelompok, peserta didik menjadi lebih baik dalam mengatur belajarnya. Sehingga peserta didik yang terlibat dalam pengerjaan tugas mencapai $85,51 \%$, peserta didik yang bertanya mencapai $18,84 \%$, peserta didik yang berani berpendapat atau menjawab pertanyaan $31,88 \%$, dan peserta didik yang mengerjakan PR mencapai $85,51 \%$. Meningkatnya keaktifan peserta didik ini berdampak pada meningkatnya persentase peserta didik yang tuntas dalam belajar menjadi 73,91\%.

Selanjutnya, pada siklus III keaktifan peserta didik dalam pembelajaran semakin meningkat sehingga mencapai indikator keberhasilan yang telah ditentukan, bahkan ada yang melebihi. Peserta didik yang terlibat dalam pengerjaan tugas mencapai $89,13 \%$, peserta didik yang bertanya mencapai $21,74 \%$, peserta didik yang berani berpendapat atau menjawab pertanyaan $36,96 \%$, dan peserta didik yang mengerjakan PR mencapai 91,31\% Hal ini merupakan akibat dari perbaikan-perbaikan yang telah dilaksanakan, antara lain: adanya jurnal refleksi kelompok dapat mengatasi keterbatasan waktu untuk menjawab setiap pertanyaan peserta didik, setiap peserta didik menerima LKS sehingga dapat lebih memaksimalkan belajarnya, pembentukan kelompok diserahkan pada peserta didik namun tetap dikontrol agar memenuhi heterogenitas kemampuan akademik, peserta didik perempuan membentuk kelompok sendiri sehingga tidak canggung dalam berdiskusi. Seiring dengan meningkatnya keaktifan peserta didik dalam pembelajaran, meningkat pula ketuntasan belajar peserta didik. Ketuntasan klasikal mencapai 82,61\%. 
Berkaitan dengan ketuntasan hasil belajar secara individual, pada siklus III masih terdapat 4 peserta didik yang belum tuntas. Keempat peserta didik tersebut juga tidak tuntas hasil belajarnya pada siklus I dan II. Dari hasil observasi, menunjukkan bahwa keempat peserta didik tersebut sering tidak mengerjakan tugas dan jarang terlibat dalam diskusi kelompok. Selain itu seorang peserta didik pernah tidak masuk sekolah sehari pada siklus II, dan seorang lagi pada siklus ke III dengan alasan sakit. Hal ini dapat menyebabkan berkurangnya pengusaan mereka terhadap materi pelajaran.

Dengan melihat hasil yang dicapai dalam penelitian ini maka dapat dikatakan bahwa pemanfaatan jurnal refleksi sebagai strategi metakognitif dapat meningkatkan keaktifan dan hasil belajar peserta didik kelas IX-A SMPN 2 Winongan pada materi Kesebangunan.

\section{SIMPULAN}

Berdasarkan hasil penelitian dapat disimpulkan bahwa pembelajaran dengan memanfaatkan jurnal refleksi sebagai strategi metakognitif dapat meningkatkan keaktifan dan hasil belajar kesebangunan peserta didik kelas IX-A SMPN 2 Winongan.

\section{DAFTAR PUSTAKA}

Anggraeni, S. (2009). Pengaruh Penggunaan Jurnal Belajar (Learning Journal) Terhadap Hasil Belajar Peserta didik pada Konsep Sistem Reproduksi Manusia. Universitas Pendidikan Indonesia.

Dwianto, A. (2010). Pengertian, Kegunaan, dan Bentuk Jurnal Belajar. Retrieved December 24, 2015, from http://www.sangpengajar.com/2010/08/pengertiankegunaan-dan-bentukjurnal_02.html.

Erman, S. dkk. (2001). Strategi Pembelajaran Matematika Kontemporer. Bandung: JICAUniversitas Pendidikan Indonesia.

Fadllia, A. (2012). Pengaruh Pembuatan Jurnal Belajar Dalam Pendekatan Jelajah Alam Sekitar (JAS) Terhadap Hasil Belajar Peserta didik Pada Materi Ekosistem. Universitas Negeri Semarang.

Febriyanti, W. P. (2009). Keefektifan Pendekatan Keterampilan Metakognitif dalam Pembelajaran Matematika pada Pencapaian Hasil Belajar Peserta didik SMP Kelas VI. Universitas Negeri Semarang.

Kemendikbud. (2016). Peraturan Menteri Pendidikan Nasional Nomor 22 Tahun 2016 tentang Proses Pembelajaran. Jakarta: Kemendikbud.

Septiyana, K. (2012). Penerapan Jurnal Belajar Sebagai Strategi Berpikir Metakognitif Pada Materi Sistem Imunitas Terhadap Hasil Belajar Peserta didik SMA Negeri 1 Kajen. Universitas Negeri Semarang.

Shadiq, F. (2013). Metakognisi: Apa dan Mengapa Penting? Retrieved July 16, 2016, from http://p4tkmatema-tika.org/2013/12/metakognisi-apa-dan-mengapapenting/ 
Sukidin, B., \& Suranto. (2002). Manajemen Penelitian Tindakan Kelas. Bandung: PT Insan Cendekia.

Suprijono. (2010). Cooperative Learning Teori dan Aplikasi Paikem. Yogyakarta: Pustaka Pelajar.

Teasdale, J. D., Moore, R. G., Hayhurst, H., Pope, M., \& Williams, S. (2002). Metacognitive Awareness and Prevention of Relapse in Depression: Empirical Evidence. Journal of Consulting and Clinical Physicology, 70(2), 275-287. https://doi.org/10.1037//0022-006X.70.2.275

Usaid Prioritas. (2013). Praktik Yang Baik di Sekolah Menengah Pertama/Madrasah Tsanawiyah 1. Jakarta: Usaid Prioritas. 